\title{
Statyba
}

\section{ANALYSIS OF COMPLICATED FORM SECTIONS OF STEEL MEMBERS}

\section{A. Daniūnas}

To cite this article: A. Daniūnas (1997) ANALYSIS OF COMPLICATED FORM SECTIONS OF

STEEL MEMBERS, Statyba, 3:9, 34-38, DOI: 10.1080/13921525.1997.10531669

To link to this article: https://doi.org/10.1080/13921525.1997.10531669

曲 Published online: 26 Jul 2012.

Submit your article to this journal 2

Џ Article views: 47 


\section{ANALYSIS OF COMPLICATED FORM SECTIONS OF STEEL MEMBERS}

\section{A. Daniūnas}

\section{Summary}

Strain-deformed state analysis of free form sections of steel members is defined in an elasticplastic state while using the extremum energy principles of elastic-plastic systems [1]. The solution is obtained by using finite elements with the constant distribution of stresses.

\section{Introduction}

The steel structure design codes $[2,3,4]$ require to check up the member strength when evaluating plastic deformations. The model of perfectly plastic material is accepted. The strength criteria for simple cross-sections (I-section etc) of steel members are given in design codes. The analytical steel criteria for simple cross sections are investigated in $[5,6]$ and other articles. However, evaluating, complicated cross sections (open thin-walled and so on) that are used in contemporary steel constructions, it is necessary to extend the given strength criterion range in design codes or to use modern methods of checking the carrying capacity of cross-sections. The latter could be broadly used in CAD systems.

One of the ways for checking the carrying capacity of cross-sections is the use of methods that are applied for defining strain-deformed state of elastic perfectly plastic systems. A method of defining limit internal forces having any number of internal forces combinations is proposed in [7].

In this article, the strain-deformed state of crosssection is defined and at the same time the carrying capacity of cross-section is checked according extremum energy principles of elastic potential of residual stresses and complementary work of residual displacements. It is very important to define the deformed state because in some design codes, for example [3], the strength criteria are obtained when limiting the residual deformations in cross section boundary layer.

The methods offered here could be used not only for cross-sections of steel members but also for analysis of the cross-sections combined from different materials.

\section{The formulation of problem}

The actual strain-deformed state is defined using the above-mentioned extremum principles. The mathematical expression of these principles for discrete system, using linear yield conditions, is as follows [1]:

Static formulation

$$
\begin{aligned}
& \frac{1}{2} \boldsymbol{S}_{r}[D] \boldsymbol{S}_{r} \rightarrow \min , \\
& {[\Phi] \boldsymbol{S}_{r} \leq \boldsymbol{S}_{0}-[\Phi] \boldsymbol{S}_{e},} \\
& {[A] \boldsymbol{S}_{r}=\mathbf{0} .}
\end{aligned}
$$

Kinematic formulation

$$
\begin{aligned}
& \left\{-\frac{1}{2} \boldsymbol{S}_{r}^{T}[D] \boldsymbol{S}_{r}^{T}+\lambda^{T}[\Phi] \boldsymbol{S}_{e}-\lambda^{T} S_{0}\right\} \rightarrow \max , \\
& {[D] \boldsymbol{S}_{r}+[\Phi]^{T} \lambda-[A]^{T} \boldsymbol{u}_{r}=0,} \\
& \lambda \geq 0 .
\end{aligned}
$$

In mathematical models (1) and (2), - the vectors of actual, residual, elastic and limit stresses respectively: $[A]$ is the coefficient matrix of equilibrium equations, $[\Phi]$ is the coefficient matrix of yield conditions, $[D]$ is the flexibility matrix of discrete system, $\lambda$ is the vector of plastic multiplyings, $u_{r}$ is the vector of residual displacements. Solving the quadratic programming problems (1) and (2), vectors $S_{r}, \lambda, u_{r}$ are obtained. The actual strain-deformed state is obtained in the following way: 


$$
\begin{aligned}
& \boldsymbol{S}=\boldsymbol{S}_{e}+\boldsymbol{S}_{r}, \\
& \boldsymbol{u}=\boldsymbol{u}_{e}+\boldsymbol{u}_{r}, \\
& \boldsymbol{q}=\boldsymbol{q}_{e}+\boldsymbol{q}_{r},
\end{aligned}
$$

Here $\boldsymbol{u}, \boldsymbol{u}_{e}, \boldsymbol{u}_{r}, \boldsymbol{q}, \boldsymbol{q}_{e}, \boldsymbol{q}_{r}$ are the vectors of actual, elastic and residual displacements and deformations respectively.

\section{The main discrete relationships}

In this article the relationships of finite elements for the static formulation of problem (1) are formed so, that the kinematic formulation (2) relationships could be obtained in a formal way using the theory of duality.

The cross-section of steel member using finite element method is divided into free form plane elements. The constant distribution of strains along the finite element is accepted. The constant distribution of stresses does not require the continuity of strains between the elements and enables to evaluate possible breaks of strains which can occur using the elastic perfectly plastic material model.

The cross-section is analysed in $x, y, z$ coordinate system. All relationships for finite elements given below are for the actual strain-deformed state. These relationships have the same form for elastic and residual strain-deformed states.

The approximating strain matrix for element $k$, when the distribution of strains along the element is constant, is expressed by:

$$
\left[N_{k}(y, z)\right]=[E],
$$

here $[E]$ is unit matrix.

The strained state of element is defined by a vector

$$
\boldsymbol{S}_{k}=\int_{A_{k}}\left[N_{k}(y, z)\right] \sigma d a=A_{k} \sigma,
$$

here $\boldsymbol{s}_{k}=\left|N_{k x}, Q_{k y}, Q_{k z}\right|^{T}$ is vector of finite element forces, $N_{k x}$ and $Q_{k y}, Q_{k z}$ are the axial and shear forces added at the gravity centre of element, $\sigma=\left|\sigma_{x x}, \tau_{x y}, \tau_{x z}\right|^{T}$ is strain vector, $A_{k}$ is area of finite element.
The flexibility matrix of the element, evaluating transition from strains to generalized stresses, is obtained in the following way:

$$
\left[D_{k}\right]=\int_{A_{k}} \frac{1}{A_{k}}[D] \frac{1}{A_{k}} d a,
$$

here the flexibility matrix has this expression:

$$
[D]=\left[\begin{array}{cc}
\frac{1}{E} & \\
& \frac{1}{\psi G} \\
& \frac{1}{\psi G}
\end{array}\right],
$$

where $E$ is modulus of elasticity, $G$ is modulus of shear, $\psi$ is coefficient of cross-section form.

Having the integrated expression (6), we obtain the flexibility matrix of element:

$$
\left[D_{k}\right]=\left[\begin{array}{cccc}
\frac{1}{E A_{k}} & & \\
& \frac{1}{\psi G A_{k}} & \\
& & \frac{1}{\psi G A_{k}}
\end{array}\right] .
$$

The equilibrium equations express the balance between the element stresses and internal forces of cross-section. During the strains these equations are written in this way:

$$
\int_{A}[A(x, y, w)] \sigma d a=F,
$$

here $\boldsymbol{F}=\left|N_{x}, M_{y}, M_{z}, M_{w}, M_{x}, Q_{y}, Q_{z}\right|^{T}$ is vector of cross-section internal forces, the elements of this vector are axial force, bending moments, warping moment, moment of rotation and shear forces. Matrix

$$
[A(x, y, z)]=\left[\begin{array}{llll}
1 & & \\
z & & \\
y & & \\
w & & \\
& -1 & 1 \\
& 1 & \\
& & 1
\end{array}\right] \text {, }
$$

where $w$ is section warping area. 
Having used the expression (5), the equilibrium equations for discrete cross section are described as follows:

$$
\sum_{k}\left[A_{k}\right] \boldsymbol{S}_{k}=\boldsymbol{F},
$$

here matrix $\left[A_{k}\right]$ is obtained from matrix $[A(x, y, w)]$, using the coordinates of element gravity centre and warping area centre of element $k$. It is necessary to note, that the relationship between shear strains and shear forces of cross-section depending on member type could be different.

For obtaining residual deformations according to problem (2), the yield conditions should be formed for every node surrounding of finite element using strain approximating functions [8]. This type of yield conditions, when the strain distribution is accepted as constant, is written:

$$
\int_{A_{k}}\left([\Phi][N(y, z)]\left(\sigma+\sigma^{\prime}\right)-\sigma_{0}\right) d a \leq 0,
$$

here $\sigma^{\prime}$ is residual strains, arising in the member section during manufactaring process. Performing analysis according to steel structures design codes, yield strain must be changed to yield strength, for example, $\sigma_{0}=f_{y}[2], \sigma_{0}=R_{y}[3]$.

Having integrated (11), the yield conditions acquire the expression:

$$
\left[\Phi_{k}\right] \boldsymbol{S}_{k} \leq \boldsymbol{S}_{0 k},
$$

here $\left[\Phi_{k}\right]=[\Phi], S_{0 k}=A_{k}\left(\sigma_{0}-[\Phi] \sigma^{\prime}\right)$.

The formulation of finite elements with equal strain distribution described here allows us to get the kinematic formulation of the problem using the theory of duality. Then the elements of deformation vector are axial and shear deformations in the gravity centre of element and the elements of displacement vector are the axial deformation, curvatures and shear deformations in the centre of the cross-section.

\section{Illustration}

1. An I-section with an extended upper flange (see Fig. 1.) is taken to demonstrate the given method. The cross-section internal forces-vector is
$\boldsymbol{F}=\left|N_{x}, M_{y}, M_{z}\right|^{T}$. Their magnitudes are described by product $\eta F_{0}$, where $\eta \leq 1$. The limit internal forces for the given cross-section is $F_{0}=|1624(\mathrm{kN}), 64.94(\mathrm{kNm}), 378.8(\mathrm{kNm})|^{T} . \quad$ Yield strength for flanges is $R_{y}=280 \mathrm{MPa}$ and for web is $R_{y}=210 \mathrm{MPa}$. Modulus of elasticity $E=206000 \mathrm{MPa}$.

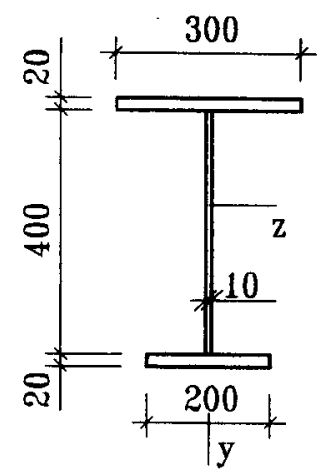

Fig. 1. Cross-section dimensions

The-cross section is analysed by loading $\eta F_{0}$. The values of coefficient $\eta$ are given in Table 1. To check the convergence of results, four variants of finite element mesh are investigated. The first variant (d1): the upper flange is covered with mesh $1 \times 6$, web $8 \times 1$, lower flange - $1 \times 4$. Respectively, the second variant (d2) - $2 \times 6,8 \times 1,2 \times 4$; the third variant (d3) $2 \times 12,16 \times 1,2 \times 8$; the fourth variant $-2 \times 12,16 \times 2,2 \times 8$.

The residual stresses, plastic multipliers and residual displacements are obtained according (1) and (2). The residual deformations in the gravity centre of element are obtained in this way:

$$
\boldsymbol{q}_{r k}=\left[D_{k}\right] \boldsymbol{S}_{r k}+\left[\Phi_{k}\right] \lambda_{k} .
$$

The elastic solution is calculated using the same scheme of finite elements as in the plastic state according to the formulas:

$$
\begin{aligned}
\boldsymbol{u}_{e} & =\left([A][D]^{-1}[A]^{T}\right)^{-1} \boldsymbol{F}, \\
\boldsymbol{s}_{e} & =[D]^{-1}[A]^{T} \boldsymbol{u}_{e}, \\
\boldsymbol{q}_{e k} & =\left[D_{k}\right] \boldsymbol{S}_{e k} .
\end{aligned}
$$

The actual stresses, deformations and displacements are obtained by (3).

In this article only characteristic calculated results are presented. The largest residual 
deformations are at the point $a$ of the cross-section. The values of these deformations are presented in Table 1. The strength criterion in the design codes [3] is obtained that when the limit value of conditional residual deformations is $\bar{\varepsilon}=\varepsilon\left(E / R_{y}\right)=3$. Then limit value for residual deformation is $\varepsilon=40810^{-5}$. It is necessary to note, that with coefficient $\eta=0.99$, residual deformations exceed the limit value of residual deformation, whereas the strength of section according (1) is sufficient.

The calculation results showed that using a finite element with constant distribution of strains along the element, the sufficient accuracy of strains can be obtained already at rough element mesh. At that time the sufficient accuracy of deformations can be obtained using only dense element mesh (see Table 1). It is understandable, when the poor bending is analysed, the sufficient accuracy of strains and deformations are reached using rough element mesh.

Table 1. Residual deformations $\varepsilon_{r a} 10^{5}$ at the point $a$

\begin{tabular}{|c|c|c|c|c|c|c|}
\hline $\begin{array}{c}\text { Ele- } \\
\text { ment } \\
\text { mesh }\end{array}$ & \multicolumn{6}{|c|}{$\eta$} \\
\cline { 2 - 7 } & 0.80 & 0.90 & 0.95 & 0.98 & 0.99 & 0.999 \\
\hline $\mathrm{d} 1$ & 4.997 & 25.50 & 51.95 & 139.8 & 278.9 & 1214 \\
\hline $\mathrm{d} 2$ & 6.247 & 29.26 & 61.61 & 228.3 & 823.1 & 8615 \\
\hline $\mathrm{d} 3$ & 5.707 & 30.01 & 61.24 & 238.1 & 755.3 & 11290 \\
\hline $\mathrm{d} 4$ & 5.702 & 29.62 & 61.23 & 238.1 & 758.4 & 11290 \\
\hline
\end{tabular}

\section{Conclusions}

The proposed method allows the use of numerical methods for analysing the strain-deformed state of complicated sections of steel members and can be successfully applied in CAD systems. The element with a constant distribution of strains allows to achieve sufficient numerical results for practical design needs.

\section{References}

1. A.Cyras. Analysis and Optimization of Elastoplastic Systems. N.Y.: John Willy \& Sons. $1983.121 \mathrm{p}$.

2. Eurocode No 3. Design of Steel Structures. Part 1. General Rules and Rules of Buildings. Vol. 1. Brussels, 1993.
3. DC II-23-81. Steel Structures. Moscow: CITP Gosstroja USSR, 1990. 96 p. (in Russian)

4. DIN 18800. Part 1. Steel Structures Analysis and Design. Berlin: Beuth Verlag GMBH. 1990. 49 p. (in German)

5. A.Mrazik, M.Čkaloud, M.Tochacek. Analysis and Design of Steel Structures in the Elasto-Plastic State. Moscow: Stroijizdat. 1986. 456 p. (in Russian)

6. H.Rubin. Interaktionsbeziechungen zwischen Biegemoment, Querkraft und Normalkraft für einfachsymmetrische I und Kasten Querschnitte bei Biegung um die starke und für doppeltsymmetrische I Querschnitte bei Biegung um die schwache Achse // Der Stahlbau, 3(1978), p. 76-85.

7. F.Werner, A.Daniūnas and A.Komka. Determination of Strength in Plastic Stage of Steel Members with General Cross-Section // Proceedings of $4^{\text {th }}$ International Conference "Modern Building Materials, Structures and Techniques", 10-13 May, Vilnius, Lithuania. Vilnius: Technika, 1995, p. 139-144.

8. A.Daniūnas. Equilibrium Finite Element Method in Analysis Problems of elasto-plastic Plates // Applied Mechanics and Optimization (Lithuanian Mechanical Rewiev, No 27). Vilnius, 1984, p. 28-39.

İteikta 19970205

\section{PLIENINIU ELEMENTU LAISVOS FORMOS SKERSPJŨVIU ANALIZE}

\section{A. Daniūnas}

S a tra u k

Plieniniu elementy laisvos formos skerspjūvio itempimų deformuoto būvio analizè ir laikomoji galia nustatoma tampriai plastinèje stadijoje, pasinaudojant tampriai plastiniy sistemy analizès ekstreminiais energetiniais principais [1]. Sių principu matematinè išraiška diskretizuotai sistemai, naudojant tiesines takumo sąlygas, yra (1) ir (2). Tikrasis įtempimų deformuotas būvis nustatomas pagal (3).

Uždavinys sprendžiamas skaitiniu būdu, naudojant baigtinių elementy metodą. Elemento skerspjüvis sudalinamas $\mathfrak{j}$ laisvos formos plokščius elementus. Baigtinį elementy priklausomybès statiniai uždavinio formuluotei sudaromos taip, kad kinematinès formuluotes priklausomybes būtụ galima gauti formaliuoju būdu naudojant dualumo teorija. Siame darbe parenkamas pastovus itempimu pasiskirstymas visame elemente. Toks itempimy pasiskirstymas nereikalauja itempimy tolydumo tarp elementų ir leidžia ivertinti galimus itempimų trūkius tarp elementy̨, kurie galimi naudojant idealiai tampriai plastinès medžiagos modeli. Siai baigtinių elementy formuluotei rasta elemento pasiduodamumu matrica (7), pusiausvyros lygtys (10) ir takumo sąlygos (12).

Pateiktai metodikai pademonstruoti imamas elemento dvitẻjis skerspjūvis su paplatinta viršutine juosta. Skerspjūvyje veikia irąžos $F=\left|N_{x}, M_{y}, M_{z}\right|^{T}$. Ju dydis 
aprašomas sandauga $\eta F_{0}$, kur $\eta \leq 1$, o $F_{0}$ yra skerspjūvio rỉbiniu ịąž̆ vektorius. Skerspjüvis tikrinamas nuo apkrovos $\eta F_{0}$. Tampriosios irąžos ir poslinkiai skaičiuojami pagal (14).

Straipsnyje pateikiami tik charakteringi skaiciavimy rezultatai. Didžiausios liekamosios deformacijos yra skerspjüvio taške a. Sių deformacijų reikšmès pateiktos lentelèje. Stiprumo sąlygos projektavimo normose [3] yra gautos laikant, kad sąlyginè ribiné liekamoji deformacija kraštiniuose skerspjūvio sluoksniuose $\bar{\varepsilon}=\varepsilon\left(E / R_{y}\right)=3$.

Tuomet ribine liekamoji deformacija $\varepsilon=40810^{-5}$. Matome, kad esant koeficientui $\eta \geq 0.99$ skerspjūvio taške a liekamosios deformacijos virsija ribinę liekamają deformaciją, nors skerspjūvio stiprumas pagal (1) yra pakankamas.
Pateikta metodika leidžia skaitiniais metodais patikrinti elementy sudètingų skerspjūviu stiprumą ir gali būti sèkmingai taikoma konstrukcijų automatizuotose projektavimo sistemose. Baigtinio elemento su pastoviu itempimy pasiskirstymu taikymas skaitiniams skaiciavimams leidžia gauti pakankamą rezultatų tikslumą, reikaling̨̨ praktiniuose skaičiavimuose.

Alfonsas DaNIŪNas. Doctor, Associate Professor. Department of Steel and Timber Structures. Vilnius Gediminas Technical University. Doctoral thesis (technical sciences) in 1985. Research interests: analysis and design of steel structures, evaluation of plastic deformations; analysis and optimization of elastic-plastic systems. 